\title{
IMPACT OF WESTERN CULTURE ON UNIVERSITY STUDENTS' LIFESTYLE
}

\author{
Dr. Azhar Majeed Qureshi \\ Assistant Professor, University of Education. Lahore, Pakistan, azhar.majeed@ue.edu.pk
}

\section{Shafia Baber}

PhD Scholar, University of Education, Lahore, Pakistan.

\section{Furrakh Abbas}

School of Languages, Civilization and Philosophy (SLCP), University Utara Malaysia

\begin{abstract}
Western culture has an extreme consequence of students' lifestyles in both positive and negative ways (Riaz \& Arif, 2017; Sibani, 2018). There is a deficiency in common apprehension about ways a culture impact students' education and lifestyle (Kang \& Chang, 2016). This research study was conducted to understand the impacts of Western culture on students' lifestyles on various campuses of the University of Education, Lahore. This descriptive study aimed to the perceptions of students about the impacts of cultural imperialism during university life. The target population in this study was both male and female undergraduate students of the University of Education in Lahore. A questionnaire based on likert scale was the tool of data collection. The data collection was through cross-sectional survey. The data collected through 130 questionnaires which were distributed and collected personally. The data analyzed through descriptive statistics (standard deviation) and inferential statistics (Chi-Square Test). The findings of the study indicate that Western culture has exceedingly impacting university students' lifestyles and social perceptions. Western culture has significantly inclined every part of university life, ranging from social adaptation to cultural preferences. The findings showed that even the slight details of daily university routines have been impacted by Western culture with mostly negative lifestyle choices.
\end{abstract}

Keywords:

Western culture, university students' lifestyles, cultural impacts

Article Received: 18 October 2020, Revised: 3 November 2020, Accepted: 24 December 2020

\section{Introduction}

The word "culture" is called a group of people, with their common ethics, customs, Values, faith, behaviors, and lifestyles (Rana \& Chishti, 2017). The conception of culture is amongst the furthermost generally used concepts of sociology. Generally, anyone is capable of assuming culture to be equal to advanced belongings of the thoughts such as skill, collected works, harmony, and image (Lebrón, 2013). Culture as a cornerstone of a civilized society evolves over a period of time. Culture as a dynamic value of society may be influenced by a number of factors ranging from political system of that country to individual lifestyles of its members. Culture as a lifestyle also incorporate different dispositions, convictions, and methods of associations etc.
Western culture has a fast-tracking effect throughout the world from the last few decades, some research supposing that Western culture may be equal to modernization (Kang, \& Chang, 2016). The global world has frequently been responsible for the speedy increase of Western culture obesity in developing countries (Colvina, Voleta, \& Fozdar, 2014). Through rapid sharing of information about the Western culture that is rapidly influenced in developing counties (Giorgetti, Campbell, \& Arslan, 2017). Sewpaul claimed in 2016 that there is a propensity to current Asian and Western "culture" as uniform and entities the dichotomy, therefore supporting essential dissertations on culture, Sewpaul also challenges by distributing through these main matters: neoliberalism, ethos, human rights and culture (Sewpaul, 2016). 
The Pakistani culture is very mixed, which collectively racial cluster originating its uniqueness initiation its individualities from cultural beliefs, values, norms and customs which ultimately creates it dissimilar from others (Giorgetti, Campbell, \& Arslan, 2017). This numerous ethnic gathering have particular social qualities and standards. The current region of Pakistan was attacked by a wide-ranging nations including British rulers. This British colonization impact not only politically or socially but also impact on thinking pattern and culture. This colonization of psyche along with globalization results in shape of different personalities.

Research conducted by Sanghera in 2010 supposed that Pakistan is a developing country and it is facing the problems and issues from the Western culture which are created because of global mass media. This current inquiry is focused to expose the consequence of global mass media in Pakistani culture through a precise focus on the portion of digital $\mathrm{TV}$ in the development of external societal designs in Pakistan (Nauman, 2015). Hussain (2016) through his research in Pakistan conveyed that the young people of Layyah city are to an unlimited effected because of relation organize. To understand that anything sorts of societal consequence have been enforced on a common community by separate TV alteration stations.

The consequences of the investigation steadfastly strengthened that external pleasure networks are significantly affecting the Pakistani young people. Due to globalization and mass media involvement from a few decades, Pakistani culture is controlling by Western culture incessantly, especially in cities of Pakistan. In both Western cultures and Pakistani culture has dissimilarities in the approach of belief, beliefs, customs, ethics, values, traditions, and lifestyle. These modifications extremely affecting all people of society specifically the adolescent group of Pakistan who start feeling pride in associating themselves with Westernization (Rana \& Chishti,
2017). The institutions of higher education particularly the universities of Pakistan are also affected by this Western culture. The responsibilities of universities to show concern about their healthy lifestyle is evident in research (Aceijas, Waldhausal, Lambert, Cassar \& BelloCorassa, 2016). The literature review also revealed a gap in the literature, that is the necessity to study how western culture impacting on university students' lifestyles (Kang \& Chang, 2016; Rana \& Chishti, 2017, Rogers, Graham, \& Mayes, 2007; Zhang, 2000).

\section{Objectives of the Study}

1. To identify the impacts of Western lifestyles on the university students' life in Punjab.

2. To know the role of mass media in promoting Western culture in universities of Punjab.

3. To clarify the impacts of Western culture on ethics, beliefs, religious festivals, and language practices of university students in Lahore.

\section{Significance of the Study}

This study has wide applications. We have selected youth to check whether Westernization influenced their social perceptions and to what extent. This will help to understand how Western culture is affecting our youth, especially university students. A quantitative survey from different campuses of Lahore will highlight huge impact of Western culture affecting Pakistani youth. We can provide information to government sector about the moral values, languages, family values and many other aspects of daily life is perceived by our future generation.

With this study results, social planners can suggest proper measures to bring Pakistani youth towards their local values and teaching of Islam. This study will be helpful to highlight whether Western culture is influences Pakistani university students in bringing positive results or not. 
Through hypothesis testing, this study will be supportive in generalizing the result in other areas of Pakistan.

\section{Research Questions}

1. Is Western culture affecting the university students' life in Punjab?

2. What is the role of mass media in promoting Western culture in the universities of Punjab?

3. Is Western culture affecting ethics, beliefs, religious festivals, and the language of university students?

\section{Null Hypothesis of the Study}

Ho1: There is no association $\mathrm{b} / \mathrm{w}$ adaption of western culture and dressing pattern

Inspired by western culture.

Ho2: there is no association b/w adaption of western culture and factor that younger people have forget about their culture and heritage.

Ho3: There is no association western culture is playing vital role in our life and way of communication with each other.

Ho4: There is no association western culture is playing vital role. in our life and preference to love marriage

Ho5: There is no association western culture is playing vital role in our life and preference to live in nuclear family.

Ho6: There is no association western culture is playing vital role in our life and parents liberalism towards children

Ho 7: There is no association western culture is playing vital role in our life and younger people are going away from their moral values.

Ho 8: There is no association western culture is playing vital role in our life and effect on

our language.
Ho 9: There is no association western culture is playing vital role in our life and likeness of western food.

Ho 10: There is no association western culture is playing vital role in our life and effect of Western culture on our festivals

\section{Literature Review}

Culture mentions the traditions and customs of the life cycle of the participants of civilization or clusters contained by the social order. It contains in what way they clothing, their wedding traditions, linguistic and domestic life cycle, their forms of effort, spiritual ceremonials, and leisureliness searches (Kuswati, 2020). The relationship between cultural values and materialism and well-being are also explored and found to be conflicting ( Karabati \& Cemalcilar, 2010). Culture is a mixture of such social deficiencies as 'the need for the sensitivity of intellectual integrity, the incredulity incorrect purpose, the hatred of power (Sewpaul, 2016).

Institutional or academic culture also had mediating impact on students and university performance (Kuh, 2002). That is an interplay between students' choices, thinking and external factors. This complexity can be multifaceted at intuitional level. Although country or cultural beginning is frequently used as a substitution for a discrete group of the follower's traditionally focused on ethics, the twofold stages might really detention dissimilar features of a mixture (Sibani, 2018). Subsurface stage pointers might be related maximum through resemblance desirability and societal uniqueness special effects, and deep stage pointers by knowledge handling and value incongruous special effects (Kuswati, 2020).

Whereas, lifestyle are set of choices and actions towards life and which may have based on personal values and beliefs or socialcultural or environmental factors (Nahas, Barros \& Francalacci, 2000). Many lifestyle choices also impacts on cultural perceptions (McGaughey, 2018). The culture of Pakistani Universities are 
identically mixed, and custom culture mentions the traditions and customs of the life cycle of the participants of civilization, or of clusters contained by the social order. It contains in what way they clothing, their wedding traditions, linguistic and domestic life cycle, their forms of effort, spiritual ceremonials, and leisureliness searches (Kuswati, 2020). Culture is multifaceted and activates at several stages (Ahmed, 2020). The attitudes and perceptions towards Western culture is influenced by the cultural factors (Lake, Staiger \& Glowinski, 1999). Although country or cultural beginning is frequently used as a substitution for a discrete group of the follower's traditionally focused on ethics, the twofold stages might really detention dissimilar features of the mixture (Sibani, 2018). Modern Western culture can destabilize universal values and time tested wisdom and may backs the cultural development of that society (Eckersley, 2005).

The ethos and culture of Pakistan are identically mixed, which to each cultural cluster originating its individuality from its appearances traditional ethics and customs which ultimately creates it different from others (Giorgetti, Campbell, \& Arslan, 2017). The culture of Pakistan is extremely diverse, through many cultural assemblies that have specific societal potentials and values (Hussain, 2016). The area presently identified as Pakistan was criticized by an extensive variety of cultures or clusters of individuals, the British presence the furthermost exposed and current one (Rana \& Chishti, 2017). The culture of Pakistan is extremely integrated and had many cultural assemblies with specific societal potentials and values (Hussain, 2016).

The Pakistani Culture has distinguishing by values, views and ethics and has religious inspiration. The Pakistan has sets out the Islamic moral guidelines for the Pakistani society (Nauman, 2015). Due to the Westernization of cultural reworked copy, Pakistani society are effected. Society of Pakistan accept the effects West and modernization, permitting to native requirements and apprehensions (Rana \& Chishti, 2017). Similarly, negative values like materialism and individualism also impacting the social life of youth. Due to these impacts Pakistani youth is making a shift in their cultural perceptions and rejecting the local cultural values and individualistic lifestyle.

Educational organizations, professors, and informative resources reckoning amongst the utmost operative agents of cultural expansion, modification, and maybe even "transmission" (Giorgetti, Campbell, \& Arslan, 2017). The educational institutions especially the universities of Pakistan are also affected by lifestyle of its students. Here is a need to identify the impacts of Western culture and life styles in the context of Pakistani universities. Since lifestyle can be seen through individual choices which are not directly measureable (Ahmed \& Naz, 2020; Ashiq, Abbas \& Obaid, 2020), so this survey research was conducted to study the perception of university students about the impacts of Western culture and how their lifestyles especially individual choices of values, languages, and festivals are changed by these impacts.

\section{Methodology of Research}

A quantitative research technique was used for this study, so the paradigm of the research was positivism. The target population comprised of all the under graduate, post-graduate and MPhil students of University of Education, Lahore. The close ended questionnaire was constructed for data collection. Pretesting or piloting is necessary to know the workability of data collection. For this purpose, $10 \%$ of the target population was taken as a sample. After piloting of the instrument, some improvements were suggested and made. Some changes in the direction of some questions were also done to make it more reasonable and orderly. The final draft of questionnaire comprises 6 demographic features and 30 questions. In this study, the content validity of the questionnaire was approved by 
experts. The reliability of 0.957 was obtained with the help of Cronbach's appropriate alpha coefficients.

This was a cross-sectional survey study with a probabilistic sampling approach. The selected sample in this study consisted of males and females students of the different campuses. The data collected from different campuses and divisions of the University in Lahore, after scheduling and authorization from the university. In the structured questionnaires to the selected students, 130 questionnaires were distributed and the comeback percentage was $100 \%$.

\section{Data Analysis and Interpretation}

The data was analyze by using descriptive statistics (Mean \& standard deviation) and inferential statistics (Chi-Square Test). Both type of analysis were performed with the help of SPSS statistical software.

Table 1: Descriptive Statistics on Western cultural \& Students' Personal life style

\begin{tabular}{lcc}
\hline \multicolumn{1}{c}{ Statements } & Mean & Std. Deviation \\
\hline $\begin{array}{l}\text { 1.Western life style is playing a vital role in } \\
\text { changing your life style }\end{array}$ & 2.60 & 1.031 \\
$\begin{array}{l}\text { 2.Way of communication with each other is } \\
\text { affected by western culture }\end{array}$ & 2.33 & .991 \\
$\begin{array}{l}\text { 3.Do you agree Under the western influence people } \\
\text { prefer love marriage than arrange marriage }\end{array}$ & 2.25 & 1.014 \\
$\begin{array}{l}\text { 4.Under the western influence you like to live in a } \\
\text { joint family system than separately }\end{array}$ & 2.26 & 1.008 \\
$\begin{array}{l}\text { 5.Do you agree new mode of media play a vital role } \\
\text { in affecting our culture }\end{array}$ & 3.12 & 1.243 \\
Valid N (list wise) & 130 & \\
\hline
\end{tabular}

It specifies to the above table that mean of the statements regarding Western cultural \& Students' Personal life style presents that promoted by the university students is above average and range from $2.25 \quad-3.12$ which counting on the scale. 4. Respites of 1 statements are dropping in the scale of agreed. It is determined that majority of perception of the university students are agreed with the impacts of Western culture on their personal lifestyles.

Table 2: Descriptive Statistics Showing Western cultural promoting through Mass Media 


\begin{tabular}{lcc}
\hline \multicolumn{1}{c}{ Statements } & Mean & Std. Deviation \\
\hline $\begin{array}{l}\text { 6.You feel impact of T.V program on your daily life } \\
\text { schedules }\end{array}$ & 2.32 & .898 \\
$\begin{array}{l}\text { 7.T.V Talk shows are responsible for directing our point of } \\
\text { view towards western culture }\end{array}$ & 2.72 & 1.064 \\
$\begin{array}{l}\text { 8.Do you agree English movies channels are responsible } \\
\text { for directing youth towards western culture }\end{array}$ & 2.06 & .913 \\
$\begin{array}{l}\text { 9.Do you agree net cafes are responsible for directing our } \\
\text { point of view towards western culture }\end{array}$ & 2.21 & 1.032 \\
$\begin{array}{l}\text { 10.You adopt new fashion form T.V Programs. } \\
\text { 11.Do you agree Fashion shows are responsible your } \\
\text { wearing style towards western fashion }\end{array}$ & 1.81 & .769 \\
$\begin{array}{l}\text { 12.Do you agree Our dressing pattern is inspired by } \\
\text { western fashion }\end{array}$ & 2.08 & .910 \\
Valid N (list wise) & 130 & .872 \\
\hline
\end{tabular}

It specifies to the above table that mean of the statements regarding Western cultural promoting through Mass Media presents that promoted by the university students is ranging from 1.81-2.72 which counting "Mean" of the scale. 5 statements are falling in this scale. Respites of 2 statements are falling in the scale of agreed. It is determined that majority are agreed with the impacts of Western culture is promoted through mass

media.

\section{Table 3: Descriptive Statistics Showing Western Cultural \& Moral Values}

\begin{tabular}{|c|c|c|}
\hline Statements & Mean & Std. Deviation \\
\hline $\begin{array}{l}\text { 13. Do you agree Younger people forget their culture and heritage } \\
\text { due to western culture }\end{array}$ & 2.03 & .880 \\
\hline $\begin{array}{l}\text { 14.Parent's liberalism towards their children is greatly , } \\
\text { influenced by western culture }\end{array}$ & 1.98 & .853 \\
\hline $\begin{array}{l}15 . \text { Do you agree Younger people are going away from their } \\
\text { morals values by western culture }\end{array}$ & 2.00 & .768 \\
\hline $\begin{array}{l}\text { 16.Do you agree Our freedom of thought is influenced by western } \\
\text { culture }\end{array}$ & 2.02 & .757 \\
\hline $\begin{array}{l}17 . \text { Do you agree Western participation in our society is } \\
\text { influenced by western culture }\end{array}$ & 2.00 & .704 \\
\hline Valid N (list wise) & 130 & \\
\hline
\end{tabular}

It specifies to the above table that majority of respondent perceptions regarding Western cultural \& Moral values presents that promoted by the university students is ranging from 1.982.03 which counting "Mean" of the scale. 5 statements are decreasing in this scale. Respites of 0 statements is falling in the scale of agreed. It is determined that bulk of the statements are exposed satisfied. Therefore, they are agreed.

Table 4: Descriptive Statistics Showing Western Cultural Impacts on Language \& Festivals 


\begin{tabular}{ccc}
\hline Statements & Mean & Std. Deviation \\
\hline
\end{tabular}

18.Do you think We can survive without learning western

2.18 852 (English) language.

19. Do you agree the Pakistani elite society feel pride in speaking English rather than Urdu as their common language?

20. Do you agree Western culture is affected our religious .801 festivals and events.

21 . Do you agree valentines are a good event to celebrate?

22. Do you agree Mother's day and father's day is a good event to celebrate.

23. Do you agree New year is a good event to celebrate?

24. Do you agree westernization has brought old home culture in Valid N (list wise)

130
It specifies to the above table that the mean of the statements regarding Western cultural effects on Language \& festivals presents that is promoted by the university students and its range from 2.033.09 which counting "Mean" of the scale. This scale section contained 7 statements. Respites of 2 statements are falling in the scale of agreed. It is determined that the bulk of the statements are exposed to satisfaction. Therefore, they are agreed.

Table 5: Descriptive Statistics Showing Western cultural Impacts on likeness of Food

\begin{tabular}{|c|c|c|}
\hline Statements & Mean & Std. Deviation \\
\hline $\begin{array}{l}\text { 25. Do you agree elite families feel pride in exercising the } \\
\text { westernized lifestyle }\end{array}$ & 1.92 & .877 \\
\hline $\begin{array}{l}\text { 26. Do you agree the elite society of Pakistan moving away from } \\
\text { their own culture }\end{array}$ & 2.10 & .888 \\
\hline 27. Do you agree our food is more delicious than western food. & 1.94 & .921 \\
\hline $\begin{array}{l}\text { 28. Do you agree The meal preferences have changed from } \\
\text { Chapatti and rice to Subway, Pizza Hut, KFC and McDonalds. Is } \\
\text { this divergence from our culture }\end{array}$ & 2.18 & .885 \\
\hline $\begin{array}{l}\text { 29.Do you think the educational sector of Pakistan affected by the } \\
\text { western culture }\end{array}$ & 2.56 & 1.175 \\
\hline $\begin{array}{l}\text { 30. Do you agree Pakistani families are at modification due to } \\
\text { western media }\end{array}$ & 2.12 & .784 \\
\hline Valid $\mathrm{N}$ (list wise) & 130 & \\
\hline
\end{tabular}

It indicates to the above table that mean of the statements regarding Western cultural \& likeness of food presents that promoted by the university students is ranging from 1.92- 256 which counting "Mean" of the scale. The total 5 statements are falling in this category. Respites of 0 statements are falling in the scale of agreed. It is determined that bulk of the students' perceptions are exposed satisfied. Therefore, they are decided.

Table 6: Pearson Chi-Square Test for Testing Independence between Two Variables 


\begin{tabular}{|c|c|c|}
\hline Hypothesis & $\begin{array}{l}\text { Chi-square } \\
\text { p-value }\end{array}$ & Conclusion \\
\hline 01: There is no association between adaption of & 99.295 & There is \\
\hline $\begin{array}{l}\text { Western culture and dressing pattern inspired by } \\
\text { university students. }\end{array}$ & 0.0000 & $\begin{array}{l}\text { association } b / w \text { the } \\
\text { attributes. }\end{array}$ \\
\hline Ho2: There is no association between adaption of & 40.154 & There is strong \\
\hline $\begin{array}{l}\text { Western culture and factor that students have forget } \\
\text { about their culture and heritage. }\end{array}$ & 0.0001 & $\begin{array}{l}\text { association } b / w \text { the } \\
\text { attributes. }\end{array}$ \\
\hline $\begin{array}{l}\text { Ho3: There is no association Western culture is } \\
\text { playing vital role in student life and way of } \\
\text { communication with each other. }\end{array}$ & $\begin{array}{l}79.884 \\
0.0000\end{array}$ & $\begin{array}{l}\text { There is strong } \\
\text { association } b / w \text { the } \\
\text { attributes. }\end{array}$ \\
\hline $\begin{array}{l}\text { Ho4: There is no association Western culture is } \\
\text { playing vital role in students' life and younger people } \\
\text { are going away from their moral values. }\end{array}$ & $\begin{array}{c}47.0764 \\
0.0000\end{array}$ & $\begin{array}{l}\text { There is strong } \\
\text { association } b / w \text { the } \\
\text { attributes }\end{array}$ \\
\hline $\begin{array}{l}\text { Ho5: There is no association Western culture is } \\
\text { playing vital role in students' life and effect on our } \\
\text { language }\end{array}$ & $\begin{array}{c}30.606 \\
0.015\end{array}$ & $\begin{array}{l}\text { There is strong } \\
\text { association b/w the } \\
\text { attributes }\end{array}$ \\
\hline $\begin{array}{l}\text { Ho6: There is no association Western culture is } \\
\text { playing vital role in students' life and likeness of } \\
\text { Western food. }\end{array}$ & $\begin{array}{c}28.076 \\
0.025\end{array}$ & $\begin{array}{l}\text { There is strong } \\
\text { association b/w the } \\
\text { attributes }\end{array}$ \\
\hline $\begin{array}{l}\text { Ho7: There is no association Western culture is } \\
\text { playing vital role students' life and effect of Western } \\
\text { culture on Pakistani festivals }\end{array}$ & $\begin{array}{c}39.143 \\
0.001\end{array}$ & $\begin{array}{l}\text { There is strong } \\
\text { association b/w the } \\
\text { attributes }\end{array}$ \\
\hline
\end{tabular}

Table 6 show an association between different attributes using the chi-square test, and results showed that adaption of Western culture and dressing pattern inspired by western culture are highly associated. It reveals an association between the adaption of Western culture and factors that younger people have to forget about their culture and heritage. It also shows that Western culture is playing a vital role in our life is highly associated with way of communication with each other, preference of thinking that younger people are going away from their moral values, the effect of Western culture on our festivals, effect on our language and likeness of Western food.

\section{Discussion}

This study was conducted with the purpose to identify the impacts of Western culture among university students. For this purpose, a survey of all campuses of University (University of Education Lahore, Punjab). There was found a high prevalence of university students with negative lifestyle choices. That might be related to their difficulty in understanding the local culture and lifestyle. The study conducted on students' perception with respect of Western culture on its impact on their individual choices like in values, languages, and festivals, etc. were evident. The majority of them unable to focus on their individual choices independently. The main role in building these perceptions is played by media, and unfortunately, promoting Western culture in Pakistan. To explore whether the youth follow international fashion and the perception about fashion and dressing is also needed.

From the descriptive analysis, it is observed a maximum number of the respondents had a similar view regarding the impacts of Western culture on their individual choices. The 
quantity of female learners is more than the number of male learners; the age of maximum respondents was from the age group 18-20 years and had to post-graduate education. Most of the university students' parents' education was matric. Most of the respondents have family income in the range of 30,000-50,000.

The findings of this study indicate that Western culture is changing Pakistani university students' lifestyles and cultures. The culture imported from the west has influenced different part of their daily life, ranging from cuisine choices to basic human rights. These results are in conformity with other researchers like Nauman (2015) who revealed these impacts and presence of learners, wearing, and directness of relation and daring deliberations and all of their lifestyles.

The findings also showed that even the tiny information of everyday life has been pretentious by Western culture through equally positive and negative aspects that are also affecting Pakistani culture. The social order of Pakistan accepts the effects of West and modernization, permitting to native requirements and apprehensions. For instance, wearing a scarf and short shirt with oriental jeans, fraternization campsite, collaborating music, and weddings of love and so on (Rana \& Chishti, 2017).

The results of this study indicate Western culture has been the measure of the upgrading and modernization procedure, which is not any logic that may be observed as destructive. Instead, it is significant to observe and investigate the West's influence in the meantime if we are not suspicious, it might have a bad and undesirable effect on our culture, and main to the disturbance of social beliefs, norms, and traditions. The culture of Pakistan has been distinguished by values, beliefs, and ethics and has Islamic inspiration. Pakistan has set out the Islamic moral guidelines for Pakistani society (Nauman, 2015).So, the advancement towards such cultural perceptions and images of good lifestyle do not meet the psychological desires and social actualities.

\section{Recommendations}

This study was limited to only university students of Lahore Campuses only and could not cover everything related to the topic. The result of this study can be generalized in any other area of Pakistan. There is a need to promote Pakistani culture, Islamic religious activities. This study may guide the policymaker and curriculum developer to design such interventions that can foster a positive attitude towards the local culture. The lifestyle Mass media should also show the beauty of our culture through movie dramas so adoption of Pakistani lifestyles and considered part of their inherent characteristics among university students.

The findings of the study verify the negative impact of learning from Western culture. These can direct impacts on lifestyles that cannot be clearly understood by a simple measurement. There is a need to conduct future researches on how to tackle these impacts. The Pakistani youth like university students basically wants transformation, but not wants to follow the idea of the West culture. There is a need to further research in exploring such strategies which can grab these values congruity at a different level. The future studies should also look in to consideration different type of comparisons between different public and private universities. A longitudinal study focusing on different perspective of academic culture can be taking into accounts. Pakistani universities must expand their responsibilities to include the promotion of national values as part of their core value.

\section{References}

[1] Aceijas, C., Waldhäusl, S., Lambert, N., Cassar, S., \& Bello-Corassa, R. (2017). Determinants of Health-related lifestyles among university students. Perspectives in public health, 137(4), 227-236. 
[2] Ahmed, S. (2020). Cross cultural aspect of teaching of English as an international language. Competitive Education Research Journal (CERJ), 1(2), 50-61.

[3] Ahmed, S.N., \& Naz, F. (2020). Demographic factors in language learning: what matters in the language learning of children? Competitive Educational Research Journal (CERJ) 1(1), 53-67.

[4] Ashiq, U., Abbas, N., \& Obaid, A. (2020). The prospects threats of substance use and role of social and economic factors among youth: The case of higher education institutions. Competitive Social Science Research Journal, 1(2), 10-18.

[5] Chohan, M. N., Saleem, M., Abbas, F. (2018). CALL as a tool in teaching EFL in Pakistani religious institutes (Madaris): A survey of issues and challenges. Al Qalam, 23 (1), 355-368.

[6] Colvina, C., Voleta, C., \& Fozdar, F. (2014). Local university students and intercultural interactions: conceptualizing culture, seeing diversity and experiencing interactions Higher Education. Research \& Development, 33(3), 440-455, doi.org/10.1080/07294360.2013.841642

[7] Eckersley, R. (2006). Is modern Western culture a health hazard?. International journal of epidemiology, 35(2), 252-258.

[8] Giorgetti, M. F., Campbell, C., \& Arslan, A. (2017). Culture and education: looking back to culture through education, Paedagogica Historica, 53(1), 1-6, doi: 10.1080/00309230.2017.1288752.

[9] Hussain, I. (2016). A comparative study of Chinese and Pakistani culture. Retrieved from,

https://www.researchgate.net/publication/32 9714977

[10] Kang, H. \& Chang, B. (2016). Examining culture's impact on the learning behaviors of international students from confucius culture studying in western online learning context. Journal of International Students, 6(3), 779797.
[11] Karabati， S., \& Cemalcilar, Z. (2010). Values, materialism, and well-being: A study with Turkish university students. Journal of Economic Psychology, 31(4), 624-633.

[12] Kuh, G. D. (2001). Organizational culture and student persistence: Prospects and puzzles. Journal of College Student Retention: Research, Theory \& Practice, 3(1), 23-39.

[13] Kuswati, Y. (2020). The influence of organizational culture on employee performance. Humanities and Social Sciences, 3(1), 296-302. doi: 10.33258/birci.v3i1.761

[14] Lake, A. J., Staiger, P. K., \& Glowinski, H. (2000). Effect of Western culture on women's attitudes to eating and perceptions of body shape. International Journal of Eating Disorders, 27(1), 83-89.

[15] Lebrón, A. (2013). What is Culture? Merit Research Journal of Education and Review, 1(6) 126-132.

[16] McGaughey, M. (2018). The Relationship between Body Image and Lifestyle Choices in College Students. International Social Science Review, 94(2), 3.

[17] Nauman, S. (2015). Investing in education: Pakistan as a traditional society in a modern world. Journal of Education and Educational Development Article, 2(1), 50 65.

[18] Rana, A.M.K, Bashir, I. \& Abbas, F. (2020). English for future employment: The perception of Pakistani academia. Hamdard Islamicus, 43 (2), 215-223.

[19] Rana, K.A. \& Chishti, H.M. (2017). Historical Perspective of cultural diversity; an effect of cultural change on student's performance at university level in Pakistan. Pakistan Vision, 20(1), 2-10.

[20] Riaz, S., \& Arif, U. (2019). Influence of Foreign TV Programs on Fashion, Lifestyle and Language of Youth. Journal of Media Studies, 32(2).

[21] Sewpaul, V. (2016). The west and the rest divide: human rights, culture and social 
work. Journal of Human Rights and Social Work, 1(1), 30-39.

[22] Sibani, M.C. (2018). Impact of western culture on traditional African society: problems and prospects. International Journal of Religion and Human Relations, 10(1), 56-72.

[23] Zhang, L. F. (2000). University students' learning approaches in three cultures: An investigation of Biggs's 3P model. The Journal of Psychology, 134(1), 37-55. 